ks. Jan Józef Janicki

Uniwersytet Papieski Jana Pawta II w Krakowie

\title{
Zabytkowe organy w Polsce na znaczkach Poczty Polskiej
}

\section{Bazylika katedralna św. Jana Chrzciciela i św. Jana Ewangelisty w Toruniu}

Dzisiejsza Bazylika katedralna św. Jana Chrzciciela i św. Jana Ewangelisty w Toruniu w okresie średniowiecza była miejscem wyboru władz miasta i pochówku patrycjatu oraz miejscem najważniejszych uroczystości miejskich, w tym związanych między innymi z wizytami królów polskich w Toruniu. Do końca XX wieku tradycyjnie określana była jako kościół Świętego Jana, który od roku 1935 nosi tytuł bazyliki mniejszej, a od 1992 roku jest katedrą diecezji toruńskiej. Ze świątyni, którą budowano w kilku etapach od II połowy XIII wieku, powstał kościół o niskim prezbiterium kontrastującym z masywnym trójnawowym halowym korpusem nawowym z niższymi kaplicami i potężną wieżą zachodnią. Wewnątrz zachował się szereg cennych dzieł sztuki średniowiecznej i nowożytnej, między innymi zespół malowideł ściennych, krucyfiks mistyczny, kompozycja rzeźbiarska ukazująca świętą Marię Magdalenę z aniołami, ołtarz Świętego Wolfganga. Część wystroju zaginęła (między innymi figura Pięknej Madonny zastąpiona kopią z 1956 roku) lub została przeniesiona do muzeów (jak na przykład obrazy Cierniem Koronowanie i Zdjęcie z Krzyża). W kościele pochowane jest serca króla Polski Jana Olbrachta (1492-1501), są tam także pamiątki związane z Mikołajem Kopernikiem (1473-1543): chrzcielnica, epitafium jemu poświęcone i XVIII-wieczny pomnik. Na wieży kościoła znajduje się największy średniowieczny dzwon w Polsce zwany Tuba Dei (trąba Boża), odlany w 1500 roku.

Święty Jan Paweł II 7 czerwca 1999 roku podczas wizyty w Toruniu nawiedził katedrę i modlił się między innymi w tak zwanej kaplicy Mikołaja Kopernika ${ }^{1}$.

1 Por. www.pl.wikipedia.org/wiki/Bazylika_katedralna_św._Jana_Chrzciciela_i_św._Jana_ Ewangelisty (10.07.2019). 
W bazylice katedralnej w Toruniu znajdują się organy barokowe, które w 1688 roku zbudował pochodzący z Torunia Mateusz Brandtner. Umieszczone są na ścianie wschodniej nawy północnej katedry Świętojańskiej. Organy te są obecnie najstarszym i jednym z dwóch takich instrumentów w tym kościele (jeszcze do 1836 roku znajdowały się tu nawet cztery organy). Historycy podają, że nie zachowały się natomiast organy pierwotne - XV-wieczne - wzmiankowane po raz pierwszy w 1479 roku, zbudowane przez franciszkanina Bartłomieja i umieszczone w prezbiterium nad wejściem do zakrystii. Organy obecne to instrument boczny, pomocniczy, stąd jego niewielkie rozmiary. Zostały wykonane w warsztacie toruńskim i zastąpiły instrument wcześniejszy, zlokalizowany w tym samym miejscu. Głównym jego elementem są trzy wieże piszczałkowe, z których środkowa jest wyższa, i dwie bliźniacze płaszczyzny piszczałkowe pomiędzy wieżami. Całość zwieńczona jest masywnym gzymsem, a nad wieżyczkami górują wieloboczne ażurowe latarnie akustyczne. Uzupełnieniem ornamentyki są między innymi akantowe uszaki po bokach i ażurowe konsole wspierające wieżyczki. Balustrada chóru organowego jest późniejsza od samego instrumentu. Tutaj elementami zdobniczymi są cztery obrazy z postaciami muzykujących aniołów na tle obłoków, oddzielone spiralnymi kolumienkami. Dolną krawędź balustrady wieńczy ornament akantowy i duże szyszki.

Organy te zostały częściowo zniszczone przez rosyjską Armię Czerwoną w 1945 roku, a odrestaurowane zostały dopiero w latach 1979-1981 przez Pracownię Konserwacji Dzieł Sztuki z Torunia (zewnętrzna oprawa) i organmistrza Józefa Mollina z Odrów k. Chojnic (wyposażenie instrumentu) pod nadzorem Mariana Dorawy z Torunia. Organy zawierają wiatrownice klapowo-zasuwane, trzy miechy klinowe, a w manuale krótką oktawę. Instrument znajduje się na przedniej ścianie lewej nawy bocznej, stół gry wbudowany jest centralnie w cokół szafy organowej. Skala manuału: CDEFGA-c ${ }^{3}$; skala pedału: C-c ${ }^{12}$.

Barokowe organy bazyliki katedralnej Świętych Janów w Toruniu znalazły się na znaczku pocztowym w serii "Zabytkowe organy w Polsce”. Uroczysta prezentacja znaczka odbyła się w piątek (21 czerwca 2019 roku) w toruńskim Muzeum Diecezjalnym. Jest to czwarty znaczek wydany w tej serii. Wcześniej pojawiły się w niej organy z kościoła klasztornego Ojców Cystersów w Jędrzejowie, z katedry w Pelplinie oraz z franciszkańskiego kościoła Świętej Trójcy w Gdańsku. Pomysłodawcą wydawnictwa pocztowego barokowych organów z katedry toruńskiej jest Marian Dorawa, organista, konserwator oraz filatelista z Torunia, który zabiegając o realizację tego projektu przez dwadzieścia pięć lat, stwierdził:

2 www.musicamsacram.pl/instrumenty/opis/2628-Torun-Katedra-sw-Jana-Chrzciciela-i-swJana Ewangelisty (organy boczne) (10.07.2019). 
Uważam, że znak pocztowy, czyli znaczek, jest najlepszym ambasadorem mówiącym o kulturze, o historii danego kraju. W 1945 roku organy zostały zniszczone przez żołnierzy radzieckich, którzy - jak słyszałem - biegali z piszczałkami po ulicach i grali. Pod moim kierunkiem organy te były rekonstruowane. W 1983 roku Toruń obchodził 750-lecie miasta i ja, właśnie po raz pierwszy po 1945 roku, na tych organach zagrałem³.

\section{Rola znaczka pocztowego w życiu spotecznym}

Znaczek pocztowy, istniejący w kulturze europejskiej od roku 1840, pomimo istnienia w naszych czasach poczty elektronicznej i frankatury mechanicznej spełnia w życiu ludzi i społeczeństw ciągle istotną i ważną rolę́. Uważa się, że znaczek umożliwia wzajemną wymianę myśli i wartości, przypomina dzieje państw i narodów oraz jest odbiciem aktualnych stosunków społecznych, ekonomicznych oraz ustroju politycznego. Ze znaczka można odczytać i rozpoznać elementy duchowego dziedzictwa narodu, w tym też jego religijności czy też stosunku do religii. Znaczek ponadto zwraca uwagę na postacie i doniosłe wydarzenia i jest w stanie wywołać głębokie przeżycia, a także wzruszenia u oglądających, które łączą ludzi i budują swoistą ludzką solidarnośćs. W zbiorach znaczków o tematyce patriotycznej i religijnej odzwierciedla się miłość do Ojczyzny oraz wiara i miłość Kościoła; znajomość dziejów ojczystych oraz znajomość tradycji i dziejów Kościoła. Znaczki o tematyce religijnej pokazują „,wszczepienie w długi łańcuch pokoleń dających autentyczne świadectwo o Bogu i Jego dziele zbawienia urzeczywistnionym w Jezusie Chrystusie"6.

Wszyscy, którzy zbierają i rozpowszechniają znaczki mające „bezpośredni związek z wartościami wiary i ją obwieszczające”, stają się ,apostołami, ponieważ dzisiejszym ludziom, poszukującym i walczącym” wskazują na Boga, „źródło wszelkiego światła, najgłębszą przyczynę i centrum wszelkiego istnienia”, a równocześnie obwieszczają wszystkim „orędzie o niezgłębionym bogactwie Chrystusa (Ef 3, 8)”7.

3 www.radiopik.pl/2,78995, muzyczny-znaczek-prosto-z-torunia-pojdzie-w-swiat (10.07.2019).

4 Por. J. J. Janicki i jego artykuły o organach na znaczkach pocztowych w „Pro Musica Sacra” w roku 2016, 2017 i 2018.

5 Por. J. J. Janicki, Królowa Jadwiga w filatelistyce, „Analecta Cracoviensia” 29 (1997), s. 519; W. Chrostowski, Papież Pielgrzym. Jan Pawet II na znaczkach pocztowych świata 19781990, Warszawa 1991, s. 10.

6 W. Chrostowski, Filatelistyka - środkiem ewangelizacji wspótczesnego świata, w: PZF, Krajowa Wystawa Filatelistyczna „TotusTuus - Kielce '91”, Kielce 1991, s. 8.

7 Papież Paweł VI do uczestników IV Kongresu Światowej Federacji Stowarzyszeń Filatelistycznych Świętego Gabriela (wrzesień 1972), cyt. za: B. Michalak, Archaniot Gabriel-patron pocztowców i Filatelistów, „Filatelista” 50 (2003), s. 9. 
Podczas audiencji dla organizatorów i uczestników Światowej Wystawy Filatelistyki „Italia ‘85” święty Jan Paweł II powiedział, że znaczek pocztowy należy

do wybitnego wyrazu sztuki, który sam przez się jest wymowną i znamienitą formą języka powszechnego. Znaczek pocztowy bowiem nie ogranicza się tylko do celów funkcjonalnych, lecz zmierza do osiągnięcia kwalifikowanych wyrazów piękna plastycznego. Co więcej, ma na celu budzenie szczególnego zainteresowania kulturalnego, kiedy odtwarza i ilustruje pomniki, wybitne dzieła, motywy świata przyrody albo upamiętnia wydarzenia i osobistości historyczne lub wybitne postaci tak kultury powszechnej, jak i historii narodów ${ }^{8}$.

Papież zwrócił uwagę, nie tylko filatelistów, na osobliwą formę ekspresywną, dzięki której

filatelistyka staje się w ten sposób, okazyjnym, lecz skutecznym współczynnikiem informacji, wychowania i dialogu. Ileż orędzi pożytecznych dla dobra wspólnego, dla zainteresowań kolekcjonerskich lub ile korzystnych informacji może być codziennie rzuconych $\mathrm{w}$ świat przez prosty znaczek pocztowy lub przez rysunek oraz zwięzly i sugestywny zwrot specjalnego ostemplowania! Można też stwierdzić, że doniosłą misję pokoju pełni to proste i zwykłe narzędzie łączności, związane z codzienną praktyką poczty9

Święty Jan Paweł II, nie zatrzymując się na aspekcie „subtelnej przyjemności, połączonej z pasją zbierania i rozpoznawania znaczków oraz ich wartości ekonomicznej”, w dalszej części swego przemówienia do organizatorów i uczestników Światowej Wystawy Filatelistyki „Italia '85” (po francusku), stwierdził, iż

zbieranie i rozpoznawanie najrozmaitszych form, jakie przybierają znaczki pocztowe na przestrzeni czasów, pozwalają poznać różne strony życia ludzkiego i pamięci różnych narodów oraz ich kontakty. Znaczki przypominają różne okresy historii, przeszłej i współczesnej. Ukazują wybitne osobistości każdego narodu; uobecniają w pamięci obchodzone ważniejsze uroczystości, symbolizują szczególnie reprezentacyjne elementy należące do dziedzictwa przyrodniczego, artystycznego, naukowego, kulturowego, poprzez

8 Jan Paweł II, Do filatelistów. Także znaczek pocztowy jest narzędziem pokoju (28 października 1985), w: Jan Paweł II, Nauczanie papieskie, VIII, 2, 7-12.1985, Poznań 2004, s. 592.

9 Jan Paweł II, Do filatelistów, s. 592. 
które ludzkie społeczeństwa mogą się coraz lepiej poznawać. (...) Religijne przekonania często odciskają swoje piętno na historii, na cywilizacji czy na sztuce i wychowują wybitnych ludzi. Przekonania religijne znajdują swój prawowity wyraz również na znaczkach pocztowych w bardzo wielu krajach $^{10}$.

$\mathrm{Na}$ koniec papież skierował do wszystkich filatelistów, aby uświadamiali ludziom zainteresowanym zbieraniem znaczków cały sens ich zbiorów; aby poszerzali ,ich pogląd na różnorakie aspekty relacji między ludźmi, na własną charakterystykę każdego kraju oraz na jego historię, która ciągle się dokonuje, a także i na ludzkie podstawowe wartości”"11.

\section{Z historii organów}

Organy, które instrukcja $O$ muzyce w świętej liturgii Świętej Kongregacji Obrzędów z 1967 roku określa jako „tradycyjny instrument muzyczny, którego brzmienie ceremoniom kościelnym dodaje majestatu, a umysły wiernych porywa do Boga i spraw niebieskich"12, pojawiły się w kościołach Europy w VII wieku na terenie Anglii. Papież św. Witalian I (657-672) pozwolił na używanie organów w liturgii w celu wspierania wspólnotowego śpiewu wiernych ${ }^{13}$. Król Pepin Mały (†768) umieścił w kościele w Compiègne organy, które otrzymał od cesarza bizantyjskiego Konstantyna Kopronymosa. Karol Wielki $(† 814)$ polecił zbudować organy dla katedry w Akwizgranie (Aachen), wzorując się na otrzymanych od władcy arabskiego Harun-al-Raszyda. Od czasu, kiedy Giorgio Benevento z Wenecji zbudował w 825 roku organy dla cesarza Ludwika Pobożnego ( $† 840)$, budownictwo organowe w Europie zaczęło się szybko rozwijać i rozpowszechniać. Wymownym tego świadectwem jest list papieża Jana VIII (872-882) do biskupa Frezyngi, w którym prosi on o przysłanie mu organów „wraz z dobrze przygotowanym organistą do ich obsługi”"14. Na przełomie VIII i IX wieku budowano organy niewielkich rozmiarów, tak że można je było przenosić (był to tak zwany portatyw); składały się

10 Jan Paweł II, Do filatelistów, s. 593.

11 Zob. Jan Paweł II, Do filatelistów, s. 593.

12 Święta Kongregacja Obrzędów, Instrukcja Musicam sacram o muzyce w świętej Liturgii (Instructio de musica in sacra Liturgia) (5.03.1967), nr 62; zob. Instrukcja Episkopatu Polski o muzyce liturgicznej po Soborze Watykańskim II (8.02.1979), nr 28.

13 Por. T. Sinka, Organy w liturgii Kościota, „Ruch Biblijny i Liturgiczny” 51 (1998), s. 209; Leksykon liturgii, red. B. Nadolski, Poznań 2006, s. 1127.

14 T. Sinka, Organy w liturgii Kościota, s. 209. 
z dziesięciu dużych klawiszy i dwudziestu ołowianych piszczałek. W X wieku organy powiększono przez dodanie drugiej klawiatury i większej liczby piszczałek, tak aby służyły do podawania tonu przy śpiewie gregoriańskim, do podtrzymywania śpiewów podczas różnych procesji, a w czasie modlitw brewiarzowych (oficjum) pełniły rolę drugiego chóru ${ }^{15}$. Dzięki takim praktykom postępowało „usamodzielnienie się" organów, których zaczęto używać podczas większych uroczystości, świąt i ważnych wydarzeń kościelnych, jak na przykład święcenia biskupie Brunona w katedrze w Kolonii w 953 roku. Mimo że jeszcze w XII wieku organy były technicznie instrumentem słabo rozwiniętym, to jednak podobały się zarówno wiernym, jak i duchowieństwu; wielu komentatorów tamtego czasu nie szczędziło pochwał pod adresem organów, a ich brzmienie porównywali oni do muzyki aniołów ${ }^{16}$. Te i inne świadectwa z tego okresu pokazują, że organy „włączały się” do liturgii, a ich muzyka stawała się także wyrazem radości duchowych ludu Bożego; organy „przejęły rolę starotestamentalnych instrumentów towarzyszącym śpiewom psalmów” ${ }^{17}$. Z biegiem lat i wieków udoskonalane organy stawały się instrumentem liturgicznym, umieszczanym w prezbiterium, w pobliżu ołtarza, aby lepiej mogły służyć sprawowanej liturgii i jej uczestnikom. Znawcy tej problematyki piszą:

wysoka sprawność techniczna organów barokowych oraz jakość ich brzmienia stwarzały zachętę dla kompozytorów, którzy tworzyli wówczas wspaniałe fugi, toccaty, preludia czy chorały. Komponowano również małe przygrywki nawiązujące do melodii gregoriańskich i pieśni kościelnych. (...) W kościele organy pomagały się modlić nie tylko wspólnym śpiewem, ale można było także medytować czy adorować Jezusa przy dźwiękach organów grających solo ${ }^{18}$.

Święty Pius X (1903-1914) w motu proprio Tra le sollecitudini (22 listopada 1903) pisał, że jakkolwiek „właściwą muzyką kościelną jest tylko sam śpiew, niemniej jednak dozwolony jest także śpiew z towarzyszeniem organów”; „ponieważ zaś śpiew powinien zawsze mieć pierwszeństwo, to organy i inne instrumenty powinny tylko po prostu podtrzymywać go, a nie zagłuszać”; „gra na organach (...) nie tylko powinna być wykonana wedle właściwości tego instrumentu, ale powinna nadto posiadać wszystkie zalety prawdziwej muzyki kościelnej”'19.

15 T. Sinka, Organy w liturgii Kościota, s. 210; Organy, w: Leksykon liturgii, s. 1127.

16 Por. T. Sinka, Organy w liturgii Kościota, s. 210; Organy, w: Leksykon liturgii, s. 1127.

17 T. Sinka, Organy w liturgii Kościota, s. 211.

18 T. Sinka, Organy w liturgii Kościota, s. 211.

19 Motu proprio Tra le sollecitudini o muzyce świętej (22.11.1903), 15-16.18 (cyt. za: G. M. Suñol, Zasady śpiewu gregoriańskiego, tłum. M. Koziura, Poznań 1957, s. 222). 
Papież Pius XI (1922-1939) stwierdzit, że organy to

właściwy instrument muzyczny w Kościele, przekazany przez pokolenia poprzednie, który dla dziwnej swej mocy i majestatu uznany został za godny zespolenia się z obrzędami liturgicznymi, by towarzyszyć śpiewowi, albo też gdy chór milczy, wygrywać piękne melodie ${ }^{20}$.

W encyklice Musicae sacrae disciplina o muzyce kościelnej papież Pius XII (1939-1958) napisał, że organy mają w świętych obrzędach pierwszeństwo przed wszystkimi innymi instrumentami.

Dźwięki ich bowiem nadzwyczaj harmonizują ze świętymi pieniami i obrzędami, dodając im przedziwnej wspaniałości i przepychu. Wzniosłością (powaga) zaś swoją i słodyczą, organy wzruszają serca wiernych, napełniają je jakby niebiańską radością i mocno pociągają ku Bogu i rzeczom wyższym ${ }^{21}$.

Sobór Watykański II (1962-1965) w konstytucji o liturgii świętej Sacrosanctum Concilium (4 grudnia 1963) na temat organów powtórzył myśli papieża Piusa XII:

W Kościele łacińskim organy piszczałkowe należy mieć w wielkim poszanowaniu jako tradycyjny instrument muzyczny, którego brzmienie potęguje wzniosłość kościelnych obrzędów, a umysły wiernych porywa ku Bogu i rzeczywistości nadziemskiej (KL 120).

Na koniec tej krótkiej historii organów należy stwierdzić, że dotychczas organy zostały nazwane ,instrumentem liturgicznym” jedynie w przedsoborowej instrukcji Świętej Kongregacji Obrzędów o muzyce sakralnej i liturgii z 1958 roku, w której zapisano: „gra organowa towarzysząca czynnościom liturgicznym winna być starannie dostosowana do charakteru okresu lub dnia liturgicznego, do natury tych obrzędów, a także do ich poszczególnych części” (nr 66).

Księga Obrzędy btogostawieństw zaleca, by „ze względu na ścisłe powiązanie organów z muzyką i śpiewem w czasie czynności liturgicznych i nabożeństw” po-

20 Pius XI, Konstytucja apostolska Divini cultus sanctitatem (20.12.1928), nr 8 (cyt. za, Organy, w: Leksykon liturgii, s. 1127; T. Sinka, Organy w liturgii Kościota, s. 212; por. G. M. Suñol, Zasady śpiewu gregoriańskiego, s. 232).

21 Pius XII, Encyklika Musicae sacrae disciplina o muzyce kościelnej (25.12.1955), cyt. za: G. M. Suñol, Zasady śpiewu gregoriańskiego, s. 256; por. T. Sinka, Organy w liturgii Kościota, s. 213; Organy, w: Leksykon liturgii, s. 1127. 
błogosławić organy przez oddaniem ich do użytku liturgicznego. W uzasadnieniu tego obrzędu stwierdza się, iż organy „otaczane są w Kościele łacińskim szczególnym poszanowaniem, ponieważ organowy akompaniament śpiewu czy też sama muzyka organowa nadaje obrzędom uroczysty charakter, potęguje uwielbienie Boga, sprzyja modlitwie ludu i wznosi dusze do Boga"22.

Papież Benedykt XVI, poświęcając organy (nazwane jego imieniem) w Starej Kaplicy w Ratyzbonie, w dniu 13 września 2006 roku, powiedział na początku ceremonii, iż czyni to, aby mogły one „zgodnie ze swym przeznaczeniem służyć chwaleniu Boga i umacnianiu wiary"23. Podkreślił następnie, powołując się na konstytucję o liturgii świętej Soboru Watykańskiego II (nr 112), że

„śpiew kościelny, jako związany ze słowami, jest nieodzowną oraz integralną częścią uroczystej liturgii”. Oznacza to, że muzyka i śpiew są czymś więcej niż upiększeniem (być może nawet zbędnym) kultu; są bowiem częścią celebracji liturgicznej, co więcej, same są liturgią. Uroczysta muzyka sakralna w wykonaniu chóru, organów, orkiestry, połączona ze śpiewem zgromadzenia nie jest zatem dodatkiem stanowiącym oprawę liturgii i ją uprzyjemniającym, lecz istotnym sposobem czynnego uczestnictwa w sprawowaniu kultu. Organy zawsze i słusznie zresztą były nazywane «królem» wszystkich instrumentów, ponieważ odtwarzają wszystkie dźwięki stworzenia i (...) swoim brzmieniem wyrażają wszystkie ludzkie uczucia, od radości po smutek, od uwielbienia po lament. Poza tym, jak wszelka dobra muzyka, przenoszą ze sfery czysto ludzkiej ku temu, co Boskie.

22 Obrzęd btogostawieństwa organów [w:] Obrzędy btogostawieństw dostosowane do zwyczajów diecezji polskich, Katowice 1994, s. 116. Modlitwa błogosławieństwa w końcowej części brzmi: „Prosimy Cię [Boże], pobłogosław $\dagger$ te organy, aby nasze hymny pochwalne jeszcze godniej brzmiały przed obliczem Twojego majestatu. Niech nasze uwielbienia i prośby, wspierane dźwiękiem organów, wznoszą się ku Tobie w doskonałej jedności. Przez Chrystusa, Pana naszego" (Obrzęd btogostawieństwa organów, s. 121). W agendzie liturgicznej diecezji opolskiej druga część modlitwy poświęcenia organów brzmi: „W tej uroczystej chwili prosimy Cię [Boże]: pobłogosław † te organy, aby rozbrzmiewały ku Twojej chwale i aby porywały nasze serca ku Tobie. A jak wiele piszczałek łączy się w harmonijne akordy, tak pozwól i nam, członkom Twojego Kościoła, jednoczyć się we wzajemnej miłości braterskiej, abyśmy kiedyś mogli śpiewać wieczny hymn chwały przed Twoim Majestatem razem z aniołami i wszystkimi Świętymi. O to prosimy przez Chrystusa, Pana naszego (Poświęcenie organów, w: Agenda liturgiczna diecezji opolskiej. Nabożeństwa, poświęcenia i btogostawieństwa, Opole 1981, s. 430n).

${ }^{23}$ Benedykt XVI, 13 września, Ratyzbona. Wszystko ku chwale Boga. Uroczystość poświęcenia organów w Starej Kaplicy, „L'Osservatore Romano”, wyd. polskie, 27 (2006), nr 11, s. 31. 
Dzięki wielkiemu bogactwu tonów, jakimi dysponują, od piano aż po potężne fortissimo, organy są instrumentem doskonalszym od wszystkich innych. Są one w stanie dać odpowiednie brzmienie wszystkim sferom ludzkiego życia. Niezliczone możliwości organów przypominają nam w pewien sposób bezmiar i wspaniałość Boga ${ }^{24}$.

W dalszej części swego przemówienia Benedykt XVI, nawiązując do śpiewanego podczas ceremonii poświęcenia organów Psalmu 150, który mówi o rogu i flecie, harfie i cytrze, cymbałach i bębnach, stwierdził, że wszystkie te instrumenty mają pomagać wielbić Boga w Trójcy Przenajświętszej. Powracając zaś do organów i ich „udziału” w tym, by liturgia nas przemieniała, papież posłużył się bardzo przekonującym, nie tylko dla organistów, porównaniem.

Liczne piszczałki i rejestry muszą w organach stanowić jedną całość. Jeśli coś się zablokuje, jeśli jedna piszczałka się rozstroi, w pierwszej chwili usłyszy to tylko bardzo wyrobione ucho. Lecz jeśli niedostrojonych piszczałek jest więcej, zaczynamy słyszeć fałszywe dźwięki i rezultat staje się nieznośny. Również piszczałki tych organów są podatne na zmiany temperatury i zmęczenie materiału. Jest to obraz naszej wspólnoty w Kościele. Tak jak w przypadku organów wprawna ręka musi je wciąż na nowo dostrajać do właściwego brzmienia, eliminując wszelkie dysharmonie, tak samo w Kościele musimy, w różnorodności darów i charyzmatów, wciąż na nowo dążý́ - dzięki komunii w wierze - do zgodności w uwielbieniu Boga i miłości braterskiej. Im bardziej pozwalamy, by poprzez liturgię Chrystus nas przemieniał, tym bardziej będziemy potrafili przemieniać również świat, promieniując w nim Chrystusową dobrocią, miłosierdziem i miłością do ludzi ${ }^{25}$.

Papież Benedykt XVI zakończył swoje przemówienie wygłoszone przy poświęceniu organów zwróceniem uwagi na fakt, że

wielcy kompozytorzy w istocie pragnęli na swój sposób wielbić swą muzyką Boga. Jan Sebastian Bach opatrzył tytuły wielu swych partytur literami S. D. G.: Soli Deo Gloria - Bogu jedynemu chwała. Również Anton Bruckner wpisywał na początku utworu słowa: „Poświęcone dobremu Bogu”. Niech ta wspaniała bazylika dzięki swej architektonicznej wielkości i liturgii wzbogaconej harmonijnym brzmieniem nowych organów oraz

24 Benedykt XVI, 13 września - Ratyzbona, s. 32.

25 Benedykt XVI, 13 września-Ratyzbona, s. 32. 
uroczystym śpiewem pomaga wszystkim, którzy w niej bywają, zaznawać radości wiary! ${ }^{26}$.

\section{Bibliografia}

Chrostowski W., Papież Pielgrzym. Jan Pawet II na znaczkach pocztowych świata 19781990, Warszawa 1991.

Chrostowski W., Filatelistyka - środkiem ewangelizacji wspótczesnego świata, w: PZF, Krajowa Wystawa Filatelistyczna „TotusTuus - Kielce' 91”, Kielce 1991.

Filatelistycznych Świętego Gabriela (wrzesień 1972) w: B. Michalak, Archaniot Gabriel-patron pocztowców i filatelistów, „Filatelista” 50 (2003), s. 9.

Instrukcja Episkopatu Polski o muzyce liturgicznej po Soborze Watykańskim II (8.02.1979).

Janicki J. J., Królowa Jadwiga w filatelistyce, „Analecta Cracoviensia” 29 (1997), s. 519-552. Janicki J. J., Zabytkowe organy w Polsce na znaczkach Poczty Polskiej, „Pro Musica Sacra” 14 (2016), s. 163-172.

Janicki J. J., Zabytkowe organy w Polsce na znaczkach Poczty Polskiej, „Pro Musica Sacra” 15 (2017), s. 261-267.

Janicki J. J., Zabytkowe organy w Polsce na znaczkach Poczty Polskiej, „Pro Musica Sacra” 16 (2018), s. 251-259.

Jan Paweł II, Do filatelistów. Także znaczek pocztowy jest narzędziem pokoju (28.10.1985), w: Jan Paweł II, Nauczanie papieskie, VIII, 2, 7-12.1985, Poznań 2004, s. 592.

Organy, w: Leksykon liturgii, red. B. Nadolski, Poznań 2006, s. 1126-1128.

Paweł VI, Przemówienie do uczestników IV Kongresu Światowej Federacji Stowarzyszeń Pawlak I., Organy - instrument liturgiczny, „Liturgia Sacra” 1-2 (1996), s. 79-85.

Pius X, motu proprio Tra le sollecitudini o muzyce świętej (22.11.1903),15-16.18, tłum. w: G. M. Suñol, Zasady śpiewu gregoriańskiego, tłum. M. Koziura, Poznań 1957, s. 213-225.

Pius XI, konstytucja apostolska Divini cultus sanctitatem (20.12.1928), nr 8, tłum. w: Organy, w:, Leksykon liturgii, red. B. Nadolski, s. 1127.

Pius XII, encyklika Musicae sacrae disciplina o muzyce kościelnej (25.12.1955), tłum. w: G. M. Suñol, Zasady śpiewu gregoriańskiego, tłum. M. Koziura, s. 242-262.

Święta Kongregacja Obrzędów, Instrukcja Musicam sacram o muzyce w świętej Liturgii (Instructio de musica in sacra Liturgia) (5.03.1967), $\mathrm{nr} 62$.

26 Benedykt XVI, 13 września - Ratyzbona, s. 32. 


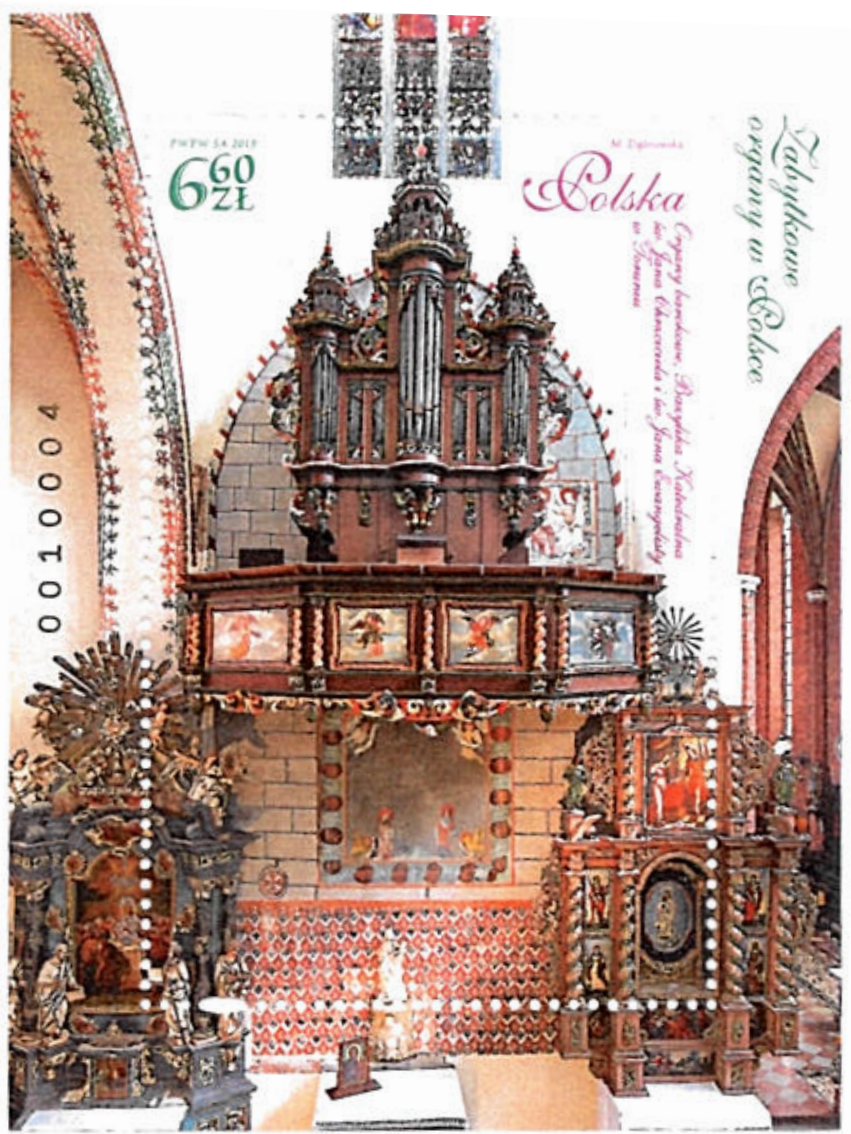

